\title{
PENGARUH KETEGASAN SANKSI, PENGETAHUAN, TAX AMNESTY, KUALITAS PELAYANAN FISKUS, KESADARAN, PENERAPAN E-SPT, TERHADAP KEPATUHAN WAJIB PAJAK ORANG PRIBADI
}

\author{
Suci Fitriyani ${ }^{1}$, Muhammad Yusuf ${ }^{2}$, Yohani $^{3}$ \\ ${ }^{123}$ Program Studi S1Akuntansi FEB UMPP \\ Email : mas.yusuf38@yahoo.co.id
}

\begin{abstract}
This study aims to examine the effect of several independent variables such as the firmness of tax sanctions, tax knowledge, tax amnesty, the quality of tax authorities, taxpayer awareness, the application of e-spt to the dependent variable, namely the compliance of individual taxpayers in the KPP Pratama Batang. The sample used in this study were 100 respondents with calculated using the Slovin formula. The method of determining the sample used in this study is the accidental sampling method (accidental sampling by taking cases or respondents who happen to be available or available somewhere in the context of the study), while the data processing method used is multiple linear regression analysis using the program SPSS 16.0.

The results of this study indicate that 1) The firmness of tax sanctions does not significantly influence the compliance of individual taxpayers with a significance value of $0.840>0.05$. 2) Tax knowledge has no significant effect on individual taxpayer compliance with a significance value of $0.746>0.05$. 3) Tax Amnesty has a significant effect on the compliance of individual taxpayers with a significance value of $0.018<0.05$. 4) The quality of fiscal services significantly influences the compliance of individual taxpayers with a significance value of $0.048<0.05$. 5) Awareness of taxpayers has a significant effect on compliance of individual taxpayers with a significance value of $0.041<0.05$. 6) The application of E-SPT does not significantly influence the compliance of individual taxpayers with a significance value of $0.882>0.05$.
\end{abstract}

Keywords: firmness of tax sanctions, tax knowledge, Tax Amnesty, quality of tax authorities, awareness of taxpayers, application of E-SPT, compliance of taxpayers.

\section{Pendahuluan}

Indonesia adalah salah satu negara berkembang. Negara berkembang adalah suatu negara yang pendapatan rata-ratanya rendah, infrastruktur relatif masih terbelakang, dan indeks perkembangan manusia berada dibawah standar normal global. Negara berkembang dapat diartikan juga sebagai negara yang sedang membangun negaranya, baik dari segi infrastruktur, perekonomian, maupun kesejahteraan masyarakatnya. Usaha yang digunakan untuk membangun Negara tersebut dapat dibagi menjadi beberapa sektor, bisa dari sektor internal maupun dari sektor eksternal (Saktiwan Dwiatmono,2018).

Salah satu faktor pendukung pembangunan Nasional adalah bersumber dari pajak, keberadaan pajak merupajakan sumber pemasukan negara yang paling utama. 
Negara menggunakan penerimaan pajak untuk meningkatkan pembangunan Nasional, dan sampai saat ini lebih dari 50\% pembiayaan Anggaran Pendapatan dan Pembelanjaan Negara (APBN) Indonesia dibiayai dari pendapatan pajak negara. Sumber penerimaan negara yang digunakan untuk membiayai pengeluaran pemerintah dan pembangunan nasional salah satunya adalah pajak.

Usaha memaksimalkan penerimaan pajak tidak dapat hanya mengandalkan peran dari Dirjen Pajak maupun petugas pajak, tetapi dibutuhkan juga peran aktif dari para wajib pajak itu sendiri. Mengingat begitu pentingnya peranan pajak, maka pemerintah dalam hal ini Direktorat Jenderal Pajak telah melakukan berbagai upaya untuk memaksimalkan penerimaan pajak. Salah satu upaya yang dilakukan adalah melalui reformasi peraturan perundang-undangan di bidang perpajakan dengan diberlakukannya self assesment system.Self Assessment System mengharuskan wajib pajak untuk mendaftar, menghitung, membayar serta melaporkan sendiri jumlah pajak terutang yang menjadi kewajiban mereka (Tryana A.M. Tiraada, 2013)

Berdasarkan data yang dikutip melalui web (www.ortax.org), dapat dilihat bahwa Tax Ratio dimulai di tahun 2013 mengalami penurunan sampai dengan ditahun 2017, tetapi ditahun 2018 angka Tax Ratio mengalami kenaikan diangka 11,5\%, naik dari kisaran 10,7\% ditahun 2017 menjadi 11,5\% ditahun 2018, naik sebesar $0.8 \%$ dari tahun sebelumnya. Rasio Pajak (Tax Ratio) adalah perbandingan penerimaan pajak terhadap produk domestik bruto. Rasio ini merupakan alut ukur untuk menilai kinerja penerimaan pajak suatu Negara.

Dalam upaya meningkatkan kepatuhan wajib pajk, maka pemerintah harus memberlakukan sanksi pajak yang tegas, guna meningkatkan pendapatan Negara serta meningkatkan kepatuhan wajib pajak sebagai warga Negara yang baik, karena pajak merupakan sumber pendapatan Negara. Sanksi pajak merupakan jaminan bahwa ketentuan peraturan perundang-undangan perpajakan (norma perpajakan) akan dituruti /ditaati/ dipatuhi, dengan kata lain sanksi perpajakan merupakan alat pencegah agar wajib pajak tidak melanggar norma perpajakan, Mardiasmo (2009). Setiap jenis pelanggaran pajak mulai dari yang tingkatannya paling kecil sampai yang paling berat sudah tersedia ancaman sanksinya. Hal ini semakin tercermin pasca amandemen undang-undang ketentuan umum dan tata cara perpajakan (UU Nomor 28 Tahun 2007) yang berhasil menggulirkan ketentuan-ketentuan baru menyangkut sanksi seputar pelanggaran kewajiban wajib pajak dan fiskus. Peraturan itu dibuat untuk meminimalisir tindakan pelanggaran hukum yang dilakukan baik oleh wajib pajak maupun fiskus.

Dalam penelitian yang akan diteliti, studi kasus yang dipilih adalah Kantor Pelayanan Pajak (KPP) Pratama Kabupaten Batang. Dalam penelitian ini, menunjukkan bahwa adanya respon pembayaran pajak yang baik, dilihat dari pemenuhan target yang telah dicapai KPP Pratama Batang. Dikutim melalui web (www.cnbcindonesia.com) KPP Pratama Batang berhasil masuk kedalam 39 Kantor Pelayanan Pajak yang berhasil merealisasikan $100 \%$ terget penerimaan pajak.

Bukan hanya itu, melalui web resmi Direktorat Jenderal Pajak (www.pajak.go.id) untuk tahun 2019, pada April 2019 lalu, melalui Keputusan Jenderal Pajak Nomor KEP-434/PJ/2019, Direktur Jenderal Pajak mengumumkan hasil seleksi Kantor Pelayanan Pajak terbaikDirektorat Jenderal Pajak 2019. Dalam keputusanya, Robert menetapkan KPP Pratama menjadi salaha satu dari tiga KPP Pratama yang terpilih menjadi KPP yang memiliki kuat inovasi. Unit kerja yang menjadi KPP terbaik umumnya memiliki inovasi berdampak nyata, sudah berjalan 
lebih satu tahun, memiliki basis data yang akurat, serta adanya data kuantitatif yang menunjukan kemajuan pencapaian. Inovasi yang dilakukan KPP Pratama Batang yaitu membuat aplikasi yang dinamakan DIPSIE pengawasan pembayaran untuk memudahkan Account Representative (AR) dalam melakukan pengawasan terhadap wajib pajak. AR mampu melihat kenaikan dan penurunan pembayaran pajakdan fluktuasi setoran wajib pajak persektor dan per jenis pajak.

Berdasarkan (https://jateng.tribunnews.com) Kantor Pelayanan Pajak (KPP) Pratama Kabupaten Batang mencatat pada semester pertama periode bulan Januari hingga Juni tahun 2018 pendapatan pajak sebesar Rp 355 miliar dengan pencapaian 44,32 persen dari target yang telah ditentukan, dengan tingkat pertumbuhan 26,58 persen. pencapaian pajak tersebut didapatkan dari 22 sektor seperti pertanian, pertambangan, industri pengolahan, pengadaan listrik dan gas, dan lainnya. Sektor yang menyumbangkan pajak tertinggi yaitu di sektor konstruksi mencapai 30,54 persen atau sebesar Rp. 102 miliar. Berdasarkan data, dari 22 sektor yang menyumbangkan pajak terbesar yaitu sektor konstruksi mencapai 30,54 persen atau sebesar Rp 102 miliar, hal itu karena ada proyek Tol dan PLTU sedangkan yang terkecil jasa perseorangan sebesar 0,1 persen sebesar Rp. 33 juta. Merujuk pada tahun 2017 tercatat kepatuhan pajak di KPP Pratama Batang sudah mencapai 70 persen sesuai dengan patokan KPP pusat. KPP Pratama juga berupaya meningkatkan ketaatan wajib pajak sesuai dengan standar nasional yaitu sebesar 70 persen.

Untuk meningkatkan pendapatan pajak, KPP pratama melakukan langkah Ekstensifikasi dengan mendatangi sentra ekonomi dan program Intensifikasi yaitu melakukan pemeriksaan dan himbauan kepada wajib pajak. Pada tahun 2017, KPP Pratama mencatatkan prestasi dengan membukukan target 104 persen sebesar Rp. 601 miliar lebih. Dan tahun ini target meningkat sebesar 30 persen yaitu sebesar Rp. 756 miliar lebih. Dari Hasil tersebut KPP Pratama Batang menempatkan diri menjadi satu-satunya KPP dari 17 KPP di Jawa Tengah yang penerimaannya pajak melebihi target.

Tabel 1.1

Penerimaan Pajak KPP Pratama Batang 2014-2018

\begin{tabular}{|c|c|c|c|}
\hline Tahun & Target Penerimaan & Realisasi Penerimaan & Persentase \\
\hline 2014 & 321.070 .813 .000 & 337.857 .454 .009 & 105,23 \\
\hline 2015 & 512.703 .064 .000 & 417.608 .742 .863 & 81,45 \\
\hline 2016 & 582.709 .004 .000 & 412.684 .773 .267 & 70,82 \\
\hline 2017 & 579.460 .331 .000 & 599.266 .447 .888 & 103,42 \\
\hline 2018 & 756.223 .147 .000 & 912.578 .930 .269 & 120,68 \\
\hline
\end{tabular}

Berdasarkan Tabel 1.1 dapat dilihat bahwa penerimaan pajak di KPP Pratama Batang mengalami kenaikan di tahun 2018, dengan pesentase pencapaian pendapatan 120,68\% dari target penerimaan yang ditetapkan. Kemudian kita juga bisa melihat bahwa persentase pencapaian penerimaan mengalami peningkatan mulai dari 103,42\% di tahun 2017, menjadi 120,68\% di tahun 2018. 
Tabel 1.2

Kepatuhan Pelaporan SPT Wajib Pajak Orang Pribadi

\begin{tabular}{|c|c|c|c|}
\hline Tahun & $\begin{array}{c}\text { WPOP Terdaftar } \\
\text { (1) }\end{array}$ & $\begin{array}{c}\text { WPOP menyampaikan SPT } \\
\text { (2) }\end{array}$ & $\begin{array}{c}\text { Rasio } \\
\text { Kepatuhan (2:1) }\end{array}$ \\
\hline 2014 & 37.484 & 17.956 & $0,48 \%$ \\
\hline 2015 & 41.047 & 18.477 & $0,45 \%$ \\
\hline 2016 & 44.007 & 20.521 & $0,47 \%$ \\
\hline 2017 & 47.584 & 18.506 & $0,39 \%$ \\
\hline 2018 & 52.664 & 18.243 & $0,37 \%$ \\
\hline
\end{tabular}

Berdasarkan Tabel 1.2 dapat dilihat bahwa tingkat kepatuhan pelaporan SPT WPOP di Batang mengalami penurunan di tahun 2018 dengan tingkat rasio sebesar 0,37\%. Tingkat rasio kepatuhan di tahun 2017 mencapai 0,39\% turun hingga menjadi $0,37 \%$ di tahun 2018. Alasan menggunakan Wajib Pajak Orang Pribadi sebagai variabel dependen penelitian yaitu dilihat dari segi penerimaan pajak KPP Batang yang selalu mengalami kenaikan penerimaan mulai dari tahun 2017, namun kenaikan penerimaan tersebut terdiri dari 22 sektor, yang menyumbangkan pajak paling besar yaitu sektor konstruksi sebesar 30,5\% (https://jateng.tribbunnews.com). Masih rendahnya kepatuhan wajib pajak dapat dilihat dalam tabel kepatuhan pelaporan SPT wajib pajak orang pribadi, yaitu dapat dilihat bahwa kesadaran wajib pajak sangatlah tergolong masih rendah, jumlah WPOP yang menyampaikan SPT tidak sebanding dengan WPOP yang terdaftar di KPP Pratama Batang. Rendahnya WPOP yang mau menyampaikan SPT memberikan gambaran bahwa masih rendanya tingkat kepatuhan wajib pajak orang pribadi dalam membayar ataupun melaporkan pajak terhutangnya.

\section{Rumusan Masalah}

Berdasarkan latar belakang yang telah diuraikan di atas, maka rumusan masalah dalam penelitian ini adalah: (1) Apakah sanksi pajak berpengaruh signifikan terhadap kepatuhan wajib wajib pajak orang pribadi? (2) Apakah pengetahuan pajak berpengaruh signifikan terhadap kepatuhan wajib wajib pajak orang pribadi? (3) Apakah Tax Amnesty berpengaruh signifikan terhadap kepatuhan wajib wajib pajak orang pribadi? (4) Apakah kualitas pelayanan fiskus berpengaruh signifikan terhadap kepatuhan wajib wajib pajak orang pribadi? (5) Apakah kesadaran wajib pajak berpengaruh signifikan terhadap kepatuhan wajib wajib pajak orang pribadi? (6) Apakah penerapan E-SPT berpengaruh signifikan terhadap kepatuhan wajib wajib pajak orang pribadi? (7) Apakah ketegasan sanksi pajak, pengetahuan pajak, Tax Amnesty, kualitas pelayanan fiskus, kesadaran wajib pajak, dan penerapana ESPT, secara bersamaan berpengaruh signifikan terhadap tingkat kepatuhan wajib pajak dalam membayar pajak pribadi?

\section{Landasan Teori}

\subsection{Theory of Planned Behavior (TPB)}

Theory of Planned Behavior didasarkan pada asumsi bahwa manusia adalah makhluk yang rasional dan menggunakan informasi- informasi yang mungkin baginya, secara sistematis. Orang memikirkan implikasi dari tindakan mereka sebelum mereka memutuskan untuk melakukan atau tidak melakukan perilakuperilaku tertentu.Dalam Theory of Planned Behavior (TPB) menjelaskan bahwa 
perilaku wajib pajak yang tidak patuh (noncompliance) sangat dipengaruhi oleh variabel dari sikap, norma subyektif, serta kontrol keperilakuan yang dipersepsikan. Perilaku yang ditimbulkan oleh individu muncul karena adanya niat untuk berperilaku. Sedangkan munculnya niat untuk berperilaku ditentukan oleh tiga faktor (Tiraada, 2013) yaitu:

\section{Behavioral Beliefs}

Behavioral beliefs merupakan keyakinan individu akan hasil dari suatu perilaku dan evaluasi atas hasil tersebut.

2. Normative Beliefs

Normative beliefs yaitu keyakinan tentang harapan normative orang lain dan motivasi untuk memenuhi harapan tersebut. Atau (normative belief) adalah kepercayaan-kepercayaan mengenai harapan-harapan yang muncul karena pengaruh orang lain dan motivasi untuk menyetujui harapan-harapan tersebut. Dari pengertian-pengertian tersebut dapat disimpulkan (normative beliefs) adalah dorongan atau motivasi yang berasal dari luar diri seseorang (orang lain) yang akan mempengaruhi perilaku seseorang tersebut.

3. Control Beliefs

Control beliefs merupakan keyakinan tentang keberadaan hal-hal yang mendukung atau menghambat perilaku yang akan ditampilkan dan persepsinya tentang seberapa kuat hal-hal yang mendukung dan menghambat perilakunya tersebut (perceived power).

\subsection{Kepatuhan Wajib Pajak}

Menurut Kamus Besar Bahasa Indonesia kepatuhan memiliki arti bahwa adanya suatu perasaan dan tindakan untuk mematuhi, tunduk dan menjalankan suatu ajaran atau peraturan yang ada. Kepatuhan adalah motivasi seseorang, atau organisasi untuk berbuat atau tidak berbuat sesuatu sesuai dengan peraturan yang telah ditetapkan (Fajriyan, 2015). Dalam pajak, aturan yang berlaku adalah undang-undang perpajakan. Kepatuhan pajak merupakan kepatuhan seseorang, dalam hal ini adalah wajib pajak, terhadap peraturan atau undang-undang perpajakan (Tiraada, 2013). Wajib Pajak memiliki beberapa kewajiban yang harus dipenuhi (Dwiatmono, 2018) yaitu:

1. Mendaftarkan diri untuk mendapatkan NPWP.

Wajib Pajak wajib mendaftarkan diri ke Kantor Pelayanan Pajak yang berada di wilayah tempat tinggal atau tempat kedudukan Wajib Pajak, kemudian akan diperoleh Nomor Pokok Wajib Pajak (NPWP). NPWP tersebut yang kemudian digunakan sebagai identitas bagi Wajib Pajak. Pendaftaran NPWP dapat dilakukan secara online melalui $e$-register.

2. Melaporkan usahanya untuk dikukuhkan sebagai PKP.

Wajib Pajak yang merupakan pengusaha yang dikenakan PPN wajib melaporkan usahanya untuk kemudian dikukuhkan sebagai Pengusaha Kena Pajak (PKP) kepada KPP. Pengukuhan sebagai PKP juga dapat dilakukan secara online melalui $e$-register.

3. Menghitung pajak terutang, memperhitungkan pajak yang sudah dipotong oleh pihak lain, membayar, dan melaporkan sendiri pajak dengan benar. Sistem perpajakan di Indonesia menganut self assessment system, sehingga Wajib Pajak diharuskan melakukan penghitungan, pembayaran, dan pelaporan pajak dengan sendiri. 
4. Mengisi dengan benar SPT (SPT diambil sendiri), dan memasukkan ke Kantor Pelayanan Pajak dalam batas waktu yang telah ditentukan. SPT merupakan surat yang digunakan Wajib Pajak untuk melaporkan penghitungan dan/atau pembayaran objek pajak sesuai dengan ketentuan peraturan perundang-undangan. Batas waktu maksimal yang telah ditentukan untuk melaporkan SPT ke Kantor Pajak adalah tiga bulan setelah akhir tahun pajak untuk SPT PPh tahunan Wajib Pajak Orang Pribadi.

5. Menyelenggarakan pembukuan atau pencatatan.

Pencatatan merupakan kumpulan data mengenai peredaran dan atau penghasilan bruto yang digunakan untuk penghitungan jumlah pajak yang terutang. Sedangkan pembukuan adalah pencatatan yang dilakukan secara teratur yang berupa data dan informasi keuangan serta jumlah harga perolehan dan penyerahan barang atau jasa, yang ditutup dengan menyusun laporan keuangan meliputi neraca dan laporan laba rugi untuk periode tahun pajak tersebut.

\subsection{Pengembangan Hipotesis}

\subsubsection{Pengaruh Ketegasan Sanksi Pajak terhadap Kepatuhan Wajib Pajak Orang Pribadi}

Sanksi pajak diterapkan oleh Direktorat Jenderal pajak pada hakikatnya untuk menciptakan kepatuhan wajib pajak dalam melaksanakan kewajiban pajaknya. Sistem pemungutan pajak yang berdasarkan atas asas self assessment system, wajib pajak diberikan kepercayaan penuh untuk menghitung menyetor dan melapor jumlah pajak yang terhutang sesuai dengan peraturan undangundang perpajakan. Namun walaupun diberikan kepercayaan, ternyata masih banyak wajib pajak yang tidak melaksanakan kewajiban perpajakanya. Atas tindakan tersebut, maka perlu dilakukanya penerapan ketegasan sanksi pajak bagi wajib pajak yang tidak taat pajak, dan diharapkan tingkat kepatuhanya akan menjadi lebih baik lagi. Berdasarkan uraian tersebut diatas dapat dirumuskan hipotesis sebagai berikut :

H1: Ketegasan sanksi pajak berpengaruh signifikan terhadap kepatuhan wajib pajak orang pribadi.

\subsubsection{Pengaruh Pengetahuan Pajak terhadap Kepatuhan Wajib Pajak Orang Pribadi}

Pengetahuan seseorang tentang peraturan perpajakan adalah sejauh mana wajib pajak mengetahui pajak yang dibebankan. Masyarakat diharapkan memiliki pengetahuan pajak tentantang peraturan perpajakan, karena untuk memenuhi kewajiban perpajakanya, pembayar pajak harus mengetahui tentang pajak terlebih dahulu. Tanpa adanya pengetahuan pajak, maka masyarakat sendiri akan susah untuk membayar pajak. Berdasarkan uraian tersebut diatas dapat dirumuskan hipotesis sebagai berikut :

$\mathrm{H}$ 2: Pengetahuan pajak berpengaruh signifikan terhadap kepatuhan wajib pajak orang pribadi

\subsubsection{Pengaruh Tax Amnesty terhadap Kepatuhan Wajib Pajak Orang Pribadi}

Tax Amnesty adalah salah satu program dari pemerintah yang ditujukan kepada para wajib pajak dalam upaya meningkatkan penerimaan pajak Negara dari pajak dengan cara menghapus pajak yang seharusnya terutang dengan membayarkan sejumlah uang dengan tujuan untuk memberikan tambahan 
penerimaan pajak untuk negara. Jika program tax amnesty ini dilaksanakan maka para wajib pajak akan memanfaatkan program tax amnesty yaitu berupa pengampunan kewajiban pajak (termasuk bunga dan denda terhutang) mereka tanpa takut dengan adanya hukuman pidana dengan membayarkan sejumlah uang. sehingga kedepannya para wajib pajak akan lebih patuh untuk melaksanakan kewajiban perpajakkannya. Kebijakan Tax Amnesty tidak hanya ditujukan pada dana yang disimpan di luar negeri tetapi kebijakan yang diberlakukan untuk semua wajib pajak di Indonesia. Adanya Tax Amnesty diharapkan wajib pajak akan secara sukarela melaporkan pajaknya dan kemudian akan patuh terhadap kewajiban perpajakannya. Berdasarkan uraian diatas dapat disimpulkan hipotesis sebagai berikut :

H3 : Tax Amnesty berpengaruh signifikan terhadap kepatuhan wajib pajak orang pribadi.

\subsubsection{Pengaruh Kualitas Pelayanan Fiskus terhadap Kepatuhan Wajib} Pajak Orang Pribadi

Pelayanan fiskus adalah pelayanan dari petugas pajak terhadap wajib pajak dalam memproses pembayaran pajak. Pelayanan fiskus sangat berpengaruh terhadap wajib pajak dalam membayar pajaknya. Pelayanan fiskus yang baik dapat mendorong seseorang untuk aktif melaporkan dan membayar pajaknya. Begitu juga dengan pelayanan fiskus yang buruk dapat membuat wajib pajak malas dalam memenuhi kewajiban pajaknya. Berdasarkan uraian tersebut diatas maka dapat disimpulkan hipotesis sebai berikut :

H4 : Kualitas pelayanan fiskus berpengaruh signifikan terhadap kepatuhan wajib pajak orang pribadi

\subsubsection{Pengaruh Kesadaran Wajib Pajak terhadap Kepatuhan Wajib Pajak Orang Pribadi}

Kesadaran wajib pajak adalah rasa sadar yang berhubungan dengan niat individu membayarkan pajaknya dengan tepat waktu. Masyarakat yang memiliki kesadaran wajib pajak akan selalu memabayarkan pajak terutangnya secara tepat. Kesadaran wajib pajak seringkali menjadi kendala dalam masalah pengumpulan pajak dari masyarakat, karena masyarakat tidak mengetahui wujud kongkrit dari uang yang dikeluarkan untuk membayar pajak. Berdasarkan uraian tersebut diatas dapat dirumuskan hipotesis sebagai berikut : H5 : Kesadaran wajib pajak berpengaruh signifikan terhadap kepatuhan wajib pajak orang pribadi

\subsubsection{Pengaruh Penerapan E-SPT terhadap Kepatuhan Wajib Pajak Orang Pribadi}

Salah satu fasilitas pajak dalam rangka modernisasi administrasi perpajakan adalah e-SPT yang merupakan aplikasi (software) yang dibuat oleh DJP untuk digunakan oleh wajib pajak untuk kemudahan dalam penyampaian SPT. Penggunaan e-SPT dimaksudkan agar semua proses kerja dan pelayanan perpajakan berjalan dengan baik, lancar, akurat serta mempermudah wajib pajak dalam melaksanakan kewajiban perpajakannya sehingga kepatuhan wajib pajak diharapkan akan meningkat. Berdasarkan uraian diatas dapat dirumuskan hipotesis sebagai berikut :

H6 : Penerapan E-SPT berpengaruh signifikan terhadap kepatuhan wajib pajak orang pribadi. 
3.3.7 Pengaruh Ketegasan Sanksi Pajak, Pengetahuan Pajak, Tax Amnesty, Kualitas Pelayanan Fiskus, Kesadaran Wajib Pajak, Penerapan E-SPT terhadap Kepatuhan Wajib Pajak Orang Pribadi.

Berdasarkan variabel-variabel bebas (independen) yaitu ketegasan sanksi pajak, pengetahuan pajak, Tax Amnesty, kualitas pelayanan fiskus, kesadaran wajib pajak, penerapan E-SPT, yang telah dijabarkan pada hipotesis $1 \mathrm{~s} / \mathrm{d} 6$, maka dalam menguji seberapa erat kaitan ketujuh variabel bebas tersebut apabila diujikan secara bersama-sama terhadap variabel terikat (dependen) yaitu kepatuhan wajib pajak, serta untuk melihat seberapa besar pengaruh keenam variabel bebas terhadap variabel terikat, diperlukan hasil penelitian dari pengujian seluruh variabel bebas (independen) yaitu ketegasan sanksi pajak, pengetahuan pajak, Tax Amnesty, kualitas pelayanan fiskus, kesadaran wajib pajak, penerapan E-SPT terhadap Variabel terikat (dependen) yaitu kepatuhan wajib pajak. Guna mendukung adanya penelitian tersebut, perlu dibentuk hipotesis ketujuh, maka dari itu dapat disimpulkan hipotesis kedelapan adalah sebagai berikut :

H7 : Ketegasan sanksi pajak, pengetahuan pajak, Tax Amnesty, kualitas pelayanan fiskus, kesadaran wajib pajak, penerapan E-SPT berpengaruh signifikan terhadap kepatuhan wajib pajak orang pribadi.

Berdasarkan Pengembangan hipotesis diatas, maka penulis menggambarkan hubungan tersebut dalam skema kerangka pemikiran sebagai berikut :

\section{Gambar 3.1 Kerangka Pemikiran}

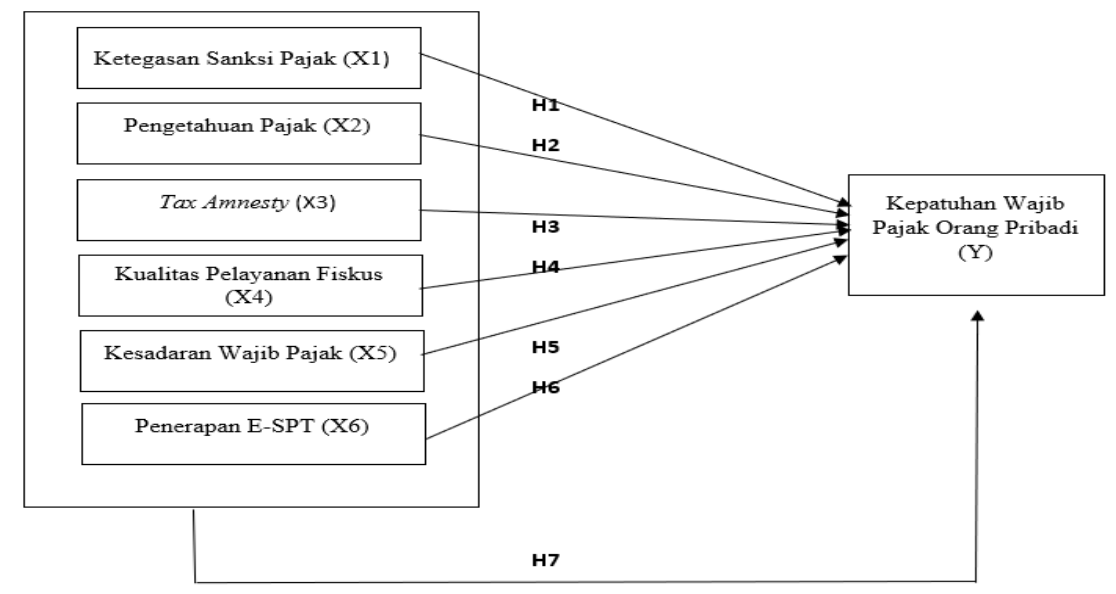

\section{Metode Penelitian}

Berdasarkan karakteristik masalah, penelitian ini merupakan penelitian asosiatif. Sugiyono (2009) mendefinisikan penelitian asosiatif merupakan penelitian yang bertujuan untuk mengetahui hubungan antara dua variabel atau lebih. Berdasarkan pendekatan data yang digunakan dalam analisis penelitian, maka penelitian ini termasuk penelitian kuantitatif. Pendekatan kuantitatif adalah metode penelitian yang digunakan untuk meneliti populasi atau sampel tertentu yang bertujuan untuk menguji hipotesis yang telah ditetapkan (Sugiyono,2015). Data yang digunakan pada penelitian ini menggunakan data primer. Data primer adalah data yang dikumpulkan dari interaksi langsung antara pengumpul dan sumber data (Wibisono, 2013). 


\subsection{Populasi dan Sampel}

Populasi adalah keseluruhan individu atau objek yang diamati dalam penelitian (Agus Widarjono 2015). Populasi dalam penelitian ini adalah wajib pajak orang pribadi yang terdaftar di Kantor Pelayanan Pajak (KPP) Pratama Batang. Populasi yang dipilih adalah seluruh Wajib Pajak Orang Pribadi yang terdaftar di KPP Pratama Batang dengan jumlah 52.664 Wajib Pajak. Mengingat cukup tingginya jumlah populasi dalam penelitian ini, maka akan dipilih beberapa yang akan dijadikan sampel. Berdasarkan kriteria diatas, sampel yang akan digunakan dalam penelitian ini berjumlah 100. Jumlah tersebut dipilih sesuai dengan Metode penarikan sampel mengacu pada pendekatan slovin,

\subsection{Prosedur Pengumpulan Data}

Jenis data yang digunakan dalam penelitian ini adalah data primer dan sekunder. Data primer adalah data yang diperoleh secara langsung dari objek baik melalui metode wawancara, kuesioner, telepon, dan sebagainya (Agus Widarjono 2015). Data sekunder didapat dari KPP Pratama Batang sebagai penunjang bukti analisis penelitian. Dapat diartikan pula bahwa data primer adalah data yang diperoleh langsung dari sumber tanpa melalui perantara. Dalam hal ini, data yang diperoleh berupa jawaban kuesioner dari sampel yang dipilih yaitu wajib pajak orang pribadi yang terdaftar di Kantor Pelayanan Pajak (KPP) Pratama Batang. Metode yang digunakan dalam penelitian ini adalah metode angket. Sampel yang sudah dipilih akan diberikan kuesioner yang berisi daftar pernyataan terkait variabel-variabel yang akan diteliti. Penyebaran kuesioner dilakukan dengan membagikan secara langsung kuesioner dalam bentuk tertulis kepada responden.

\subsection{Analisis Data}

Penelitian ini menggunakan teknik analisis regresi linier berganda guna mengetahui pengaruh dari setiap variabel independen terhadap variabel dependen. Sedangkan alat uji statistik menggunakan aplikasi SPSS Versi 16.

\subsection{Teknik Analisis}

\subsubsection{Statistik Deskriptif}

Statistik deskriptif memberikan gambaran suatu data yang dilihat dari nilai rata-rata (mean), standar deviasi, nilai maksimum, dan nilai minimum. Statistik yang berfungsi untuk mendeskripsikan atau memberi gambaran terhadap objek yang diteliti melalui data sampel atau populasi sebagaimana adanya tanpa melakukan analisis dan membuat kesimpulan yang berlaku untuk umum.

\subsubsection{Uji Instrumen Penelitian}

Uji validitas dan reliabilitas merupakan uji yang dilakukan terhadap instrument penelitian.Kedua uji ini dilakukan untuk mengetahui apakah setiap instrument penelitian layak untuk dipakai dalam penelitian. Intrument penelitian disini yaitu merupakan kuesioner.

\subsubsection{Uji Asumsi Klasik}

Pengujian regresi linear berganda dapat dilakukan setelah model dalam penelitian ini memenuhi syarat yaitu lolos dari uji asumsi klasik. Uji asumsi klasik dikenal dengan istilah Best Linier Unbiased Estimator (BLUE) digunakan untuk mendeteksi ada atau tidaknya penyimpangan asumsi klasik atas persamaan regresi berganda yang digunakan. Pengujian ini terdiri atas uji normalitas, multikolonieritas, autokorelasi dan heteroskedastisitas. 


\subsubsection{Uji Hipotesis}

Dalam penelitian ini penulis menggunakan uji hipotesis yakni, uji $\mathrm{t}$ (parsial), Uji Pengujian Variabel Mediasi dan uji koefisien determinasi (R2).

\section{Hasil dan Pembahasan}

\subsection{Hasil}

\subsubsection{Koefisien Determinasi (R2)}

Alat analisis ini digunakan untuk mengukur seberapa besar variabel dependen dipengaruhi oleh variabel independen. Nilai koefisien determinasi terlatak antara 0 hingga 1 , dimana semakin mendekati 1 , maka semakin besar kontribusi variabel independen terhadap variabel dependen. Perhitungan koefisien determinasi (R2) berdasarkan hasil SPSS versi 16 adalah sebagai berikut :

Tabel 5.1

Hasil Perhitungan Koefisien Determinasi (R2)

Model Summary

\begin{tabular}{|l|r|r|r|r|}
\hline Model & $\mathrm{R}$ & R Square & \multicolumn{1}{c|}{$\begin{array}{c}\text { Adjusted R } \\
\text { Square }\end{array}$} & \multicolumn{2}{|c|}{ Std. Error of the Estimate } \\
\hline 1 & $.516^{\mathrm{a}}$ & .266 & .219 & \\
\hline
\end{tabular}

a. Predictors: (Constant), Penerapan E-SPT, Pengetahuan Pajak, Kesadaran Wajib Pajak, Kualitas Pelayanan Fiskus, Ketegasan Sanksi Pajak, Tax Amnesty

Dari tabel koefisien determinasi, diperoleh hasil nilai koefisiensi determinasi sebesar 0,219 atau 21,9\%. Hal ini dapat dijelaskan bahwa sekitar 21,9\% kepatuhan wajib pajak dijelaskan oleh ketegasan sanksi pajak (X1), pengetahuan pajak (X2), Tax Amnesty (X3), kualitas pelayanan fiskus (X4), kesadaran wajib pajak (X5), penerapan E-SPT (X6), sedangkan sisanya sebesar $78,1 \%$ dipengaruhi faktor lain yang tidak termasuk dalam penelitian ini seperti E-system, akuntansi perpajakan, efektifitas system perpajakan, reformasi perpajakan, tingkat pendapatan.

\subsubsection{Uji Parsial (Uji T)}

Uji parsial digunakan untuk mengetahui apakah variabel independent (X) secara parsial berpengaruh signifikan terhadap variabel dependen $(\mathrm{Y})$.

Tabel 5.2

Hasil Uji Parsial (t-test)

Coefficients $^{a}$

\begin{tabular}{|c|c|c|c|c|c|c|}
\hline \multirow{2}{*}{\multicolumn{2}{|c|}{ Model }} & \multicolumn{2}{|c|}{ Unstandardized Coefficients } & \multirow{2}{*}{$\begin{array}{c}\begin{array}{c}\text { Standardized } \\
\text { Coefficients }\end{array} \\
\text { Beta }\end{array}$} & \multirow[b]{2}{*}{$t$} & \multirow[b]{2}{*}{ Sig. } \\
\hline & & B & Std. Error & & & \\
\hline \multirow[t]{7}{*}{1} & (Constant) & 6.129 & 2.093 & & 2.928 & .004 \\
\hline & Ketegasan Sanksi Pajak & .017 & .086 & .020 & .202 & .840 \\
\hline & Pengetahuan Pajak & .031 & .095 & .032 & .325 & .746 \\
\hline & Tax Amnesty & .201 & .084 & .256 & 2.409 & .018 \\
\hline & Kualitas Pelayanan Fiskus & .197 & .098 & .194 & 2.008 & .048 \\
\hline & Kesadaran Wajib Pajak & .184 & .089 & .216 & 2.075 & .041 \\
\hline & Penerapan E-SPT & .016 & .105 & .016 & .149 & .882 \\
\hline
\end{tabular}

a. Dependent Variable: Kepatuhan Wajib Pajak 
1. Hipotesis 1

Berdasarkan hasil uji t pada tabel diatas variabel ketegasan sanksi pajak (X1) memiliki nilai koefisiensi regresi sebesar 0,017 (positif). Signifikansi sebesar 0,840 nilai ini lebih besar dari $0,05(0,840>0,05)$. Oleh karena itu, dapat disimpulkan bahwa ketegasan sanksi pajak (X1) perpengaruh positif tidak signifikan terhadap kepatuhan wajib pajak (Y). Dengan demikian hipotesis pertama (H1) yang menyatakan ketegasan sanksi pajak berpengaruh signifikan terhadap kepatuhan wajib pajak ditolak.

2. Hipotesis 2

Berdasarkan hasil uji t pada tabel diatas variabel pengetahuan pajak (X2) memiliki nilai koefisiensi regresi sebesar 0,031 (positif). Signifikansi sebesar 0,746 nilai ini lebih besar dari $0,05(0,746>0,05)$. Oleh karena itu, dapat disimpulkan bahwa pengetahuan pajak (X2) perpengaruh positif tidak signifikan terhadap kepatuhan wajib pajak (Y). Dengan demikian hipotesis kedua $(\mathrm{H} 2)$ yang menyatakan pengetahuan pajak berpengaruh signifikan terhadap kepatuhan wajib pajak ditolak.

3. Hipotesis 3

Berdasarkan hasil uji t pada tabel diatas variabel Tax Amnesty (X3) memiliki nilai koefisiensi regresi sebesar 0,201 (positif). Signifikansi sebesar 0,018 nilai ini lebih kecil dari $0,05(0,018<0,05)$. Oleh karena itu, dapat disimpulkan bahwa Tax Amnesty (X3) perpengaruh positif signifikan terhadap kepatuhan wajib pajak (Y). Dengan demikian hipotesis ketiga (H3) yang menyatakan Tax Amnesty berpengaruh signifikan terhadap kepatuhan wajib pajak diterima.

4. Hipotesis 4

Berdasarkan hasil uji t pada tabel diatas variabel kualitas pelayanan fiskus (X4) memiliki nilai koefisiensi regresi sebesar 0,197 (positif). Signifikansi sebesar 0,048 nilai ini lebih kecil dari 0,05 $(0,048<0,05)$. Oleh karena itu, dapat disimpulkan bahwa kualitas pelayanan fiskus (X4) perpengaruh positif signifikan terhadap kepatuhan wajib pajak (Y). Dengan demikian hipotesis keempat (H4) yang menyatakan kualitas pelayanan fiskus berpengaruh signifikan terhadap kepatuhan wajib pajak diterima.

5. Hipotesis 5

Berdasarkan hasil uji t pada tabel diatas variabel kesadaran wajib pajak (X5) memiliki nilai koefisiensi regresi sebesar 0,184 (positif). Signifikansi sebesar 0,041 nilai ini lebih kecil dari 0,05 $(0,041<0,05)$. Oleh karena itu, dapat disimpulkan bahwa kesadaran wajib pajak (X5) perpengaruh positif signifikan terhadap kepatuhan wajib pajak (Y). Dengan demikian hipotesis kelima (H5) yang menyatakan kesadaran wajib pajak berpengaruh signifikan terhadap kepatuhan wajib pajak diterima.

6. Hipotesis 6

Berdasarkan hasil uji t pada tabel diatas variabel penerapan E-SPT (X6) memiliki nilai koefisiensi regresi sebesar 0,016 (positif). Signifikansi sebesar 0,882 nilai ini lebih besar dari $0,05(0,882>0,05)$. Oleh karena itu, dapat disimpulkan bahwa penerapan E-SPT (X6) perpengaruh positif tidak signifikan terhadap kepatuhan wajib pajak (Y). Dengan demikian hipotesis keenam (H6) yang menyatakan penerapan E-SPT berpengaruh signifikan terhadap kepatuhan wajib pajak ditolak. 


\subsubsection{Uji Simultan (Uji F)}

Uji simultan bertujuan untuk mengetahui apakah suatu variabel independent $(\mathrm{X})$ yang dimasukan dalam model regresi memiliki pengaruh yang signifikan secara bersama-sama terhadap variabel dependen (Y). Hasil F-test dapat dilihat pada output SPSS pada tabel ANOVA.

Tabel 4.3

Hasil Uji Simultan (Uji F)

ANOVA $^{\text {D }}$

\begin{tabular}{|ll|r|r|r|r|r|}
\hline Model & & Sum of Squares & df & Mean Square & F & Sig. \\
\hline 1 & Regression & 86.710 & 6 & 14.452 & 5.622 & $.000^{a}$ \\
& Residual & 239.080 & 93 & 2.571 & & \\
& Total & 325.790 & 99 & & & \\
\end{tabular}

a. Predictors: (Constant), Penerapan E-SPT, Pengetahuan Pajak, Kesadaran Wajib Pajak, Kualitas Pelayanan Fiskus, Ketegasan Sanksi Pajak, Tax Amnesty

b. Dependent Variable: Kepatuhan Wajib Pajak

Berdasarkan tabel diatas dapat dilihat bahwa hasil perhitungan yang diperoleh dari nilai uji $\mathrm{f}$ adalah 5.622 dan nilai signifikansinya sebesar 0,000 lebih kecil dari $\alpha=0,05$, maka dapat disimpulkan bahwa secara bersama-sama ketegasan sanksi pajak (X1), pengetahuan pajak (X2), Tax Amnesty (X3), kualitas pelayanan fiskus (X4), kesadaran wajib pajak (X5), dan penerapan ESPT (X6) berpengaruh secara simultan terhadap kepatuhan wajib pajak orang pribadi (Y) pada KPP Pratama Batang

\subsubsection{Analisis Regresi Linier Berganda}

Analisis ini digunakan untuk mengetahui pengaruh ketegasan sanksi pajak, pengetahuan pajak, Tax Amnesty, kualitas pelayanan fiskus, kesadaran wajib pajak, dan penerapan E-SPT pada kepatuhan wajib pajak orang pribadi di KPP Pratama Batang. Hasil pada regresi berganda ini diuji dengan menggunakan SPSS versi 16, berikut adalah hasil yang diolah :

Tabel 4.4

Hasil Analisis Regresi Linier Berganda

\begin{tabular}{|c|c|c|c|c|c|c|}
\hline \multicolumn{7}{|c|}{ Coefficients $^{a}$} \\
\hline \multirow{2}{*}{\multicolumn{2}{|c|}{ Model }} & \multicolumn{2}{|c|}{ Unstandardized Coefficients } & \multirow{2}{*}{$\begin{array}{c}\begin{array}{c}\text { Standardized } \\
\text { Coefficients }\end{array} \\
\text { Beta }\end{array}$} & \multirow[b]{2}{*}{$\mathrm{t}$} & \multirow[b]{2}{*}{ Sig. } \\
\hline & & B & Std. Error & & & \\
\hline \multirow[t]{7}{*}{1} & (Constant) & 6.129 & 2.093 & & 2.928 & .004 \\
\hline & $\begin{array}{l}\text { Ketegasan Sanksi } \\
\text { Pajak }\end{array}$ & .017 & .086 & .020 & 202 & .840 \\
\hline & Pengetahuan Pajak & .031 & .095 & .032 & .325 & .746 \\
\hline & Tax Amnesty & .201 & .084 & .256 & 2.409 & .018 \\
\hline & $\begin{array}{l}\text { Kualitas Pelayanan } \\
\text { Fiskus }\end{array}$ & .197 & .098 & .194 & 2.008 & .048 \\
\hline & $\begin{array}{l}\text { Kesadaran Wajib } \\
\text { Pajak }\end{array}$ & 184 & .089 & .216 & 2.075 & .041 \\
\hline & Penerapan E-SPT & .016 & .105 & .016 & .149 & .882 \\
\hline
\end{tabular}

a. Dependent Variable: Kepatuhan Wajib Pajak 
Berdasarkan hasil penelitian analisis regresi linier berganda dengan menggunakan SPSS versi 16, diperoleh persamaan sebagai berikut :

$\mathrm{Y}=6.129+0,017 \mathrm{X} 1+0,31 \mathrm{X} 2+0,201 \mathrm{X} 3+0,197 \mathrm{X} 4+0,184 \mathrm{X} 5+0,016 \mathrm{X} 6+\mathrm{e}$

\subsection{Pembahasan}

a. Berdasarkan hasil uji diatas, untuk variabel ketegasan sanksi pajak (X1), diketahui bahwa nilai t hitung adalah sebesar 0,202 dengan signifikansi $0,840(0,840>0,05)$. Nilai ini menunjukkan bahwa ketegasan sanksi pajak tidak berpengaruh signifikan terhadap kepatuhan wajib pajak. Dengan hasil ketegasan sanksi pajak tidak berpengaruh terhadap kepatuhan wajib pajak yang memiliki arti bahwa dengan adanya sanksi pajak yang tegaspun tidak menjamin bahwa wajib pajak akan patuh melaporkan kewajiban pajaknya. Dengan adanya sanksi pajak harusnya memberikan rasa jera agar wajib pajak tidak lalai dalam melapor dan membayar kewajiban pajaknya, namun berdasarkan hasil dari penelitian ini menunjukkan bahwa ketegasan sanksi pajak tidak berpengaruh dalam kepatuhan wajib pajak sehingga perlu dikaji ulang mengenai sanksi yang harus diberlakukan agar wajib pajak dapat selalu patuh dalam membayar pajak pribadinya.

b. Berdasarkan hasil uji diatas, untuk variabel pengetahuan pajak (X2) , diketahui bahwa nilai t hitung adalah sebesar 0,325 dengan signifikansi $0,746(0,746>0,05)$. Nilai ini menunjukkan bahwa pengetahuan pajak tidak berpengaruh signifikan terhadap kepatuhan wajib pajak.Hal ini menunjukkan bahwa pengetahuan pajak tidak berpengaruh terhadap kepatuhan wajib pajak, dengan pengetahuan yang tinggi sekalipun tidak menjamin bahwa wajib pajak akan patuh jika mereka tidak memiliki kemauan dan kesadaran dalam membayar pajak.

c. Berdasarkan hasil uji diatas, untuk variabel Tax Amnesty (X3), diketahui bahwa nilai t hitung adalah sebesar 2,409 dengan signifikansi 0,018 (0,018< 0,05). Nilai ini menunjukkan bahwa Tax Amnesty berpengaruh signifikan terhadap kepatuhan wajib pajak. Pengaruh positif yang ditunjukkan oleh tax amnesty mengindikasikan bahwa apabila tax amnesty mengalami kenaikan maka angka kepatuhan wajib pajak akan mengalami kenaikan pula, begitupun sebaliknya. Jika semua wajib pajak yang lalai membayar pajak mau mengikuti program Tax Amnesty, maka angka kepatuhan dalam membayar pajak akan meningkat pula.

d. Berdasarkan hasil uji diatas, untuk variabel kualitas pelayanan fiskus (X4), diketahui bahwa nilai t hitung adalah sebesar 2,008 dengan signifikansi $0,048(0,048<0,05)$. Nilai ini menunjukkan bahwa kualitas pelayanan fiskus berpengaruh signifikan terhadap kepatuhan wajib pajak. Dengan adanya pelayanan yang baik dari petugas pajak, maka membuat wajib pajak mau melaporkan pajaknya secara sukarela. Dengan adanya pelayanan yang baik, diharapkan dapat memberikan bantuan informasi kepada wajib pajak yang ingin menyampaikan pajaknya namun memiliki informasi pajak yang masih rendah. Dengan bantuan petugas fiskus diharapkan dapat mempermudah proses pelaporan dan pembayaran pajak.

e. Berdasarkan hasil uji diatas, untuk variabel kesadaran wajib pajak (X5), diketahui bahwa nilai t hitung adalah sebesar 2,075 dengan signifikansi $0,041(0,041<0,05)$. Nilai ini menunjukkan bahwa kesadaran wajib pajak 
berpengaruh signifikan terhadap kepatuhan wajib pajak.Dengan adanya rasa kesadaran wajib pajak yang dengan sukarela mau melakukan pelaporan dan pembayaran wajib pajak, maka akan meningkatkan kepatuhan wajib pajak itu sendiri. Semakin tinggi tingkat kesadaran maka akan semakin tinggi pula kepatuhan wajib pajak.

f. Berdasarkan hasil uji diatas, untuk variabel penerapan E-SPT (X6) , diketahui bahwa nilai t hitung adalah sebesar 0,108 dengan signifikansi $0,914(0,914>0,05)$. Nilai ini menunjukkan bahwa penerapan E-SPT tidak berpengaruh signifikan terhadap kepatuhan wajib pajak.Dengan adanya program E-SPT tersebut diharapkan data memberikan peningkatan kepatuhan pajak, karena mengingat pelaporan E-SPT sangat fleksibel bisa dilakukan kapan saja dan dimana saja, tanpa harus datang dan antri di Kantor Pelayanan Pajak (KPP) sehingga dapat diharapkan mampu meningkatkan kepatuhan wajib pajak. Hasil jawaban responden menunjukan bahwa peneran E-SPT tidak berpengaruh signifikan terhadap kepatuhan wajib pajak, dalam pelaksanaanya sebenarnya wajib pajak mau melakukan pelaporan SPT secara online, namun masih rendahnya informasi mereka yang tidak mengetahui bagaimana cara pelaporan menggunakan E-SPT. Rendahnya pengetahuan tersebut mendorong masyarakat untuk tidak melaporakan pajaknya melalui sistem yang sudah online.

\section{Kesimpulan}

a. Variabel ketegasan sanksi pajak tidak berpengaruh signifikan terhadap tingkat kepatuhan wajib pajak orang pribadi (t hitung $=0,202$ dan sig $0,840(0,840>$ $0,05)$ ).Hal ini menunjukkan bahwa ketegasan sanksi pajak yang telah dibuat oleh pemerintah tidak memberikan pengaruh terhadap kepatuhan pajak.

b. Variabel pengetahuan pajak tidak berpengaruh signifikan terhadap tingkat kepatuhan wajib pajak orang pribadi dengan t hitung $=0,325$ dan sig 0,746 $(0,746>0,05$. Hal ini menunjukkan bahwa dengan pengetahuan yang tinggi sekalipun tidak menjamin bahwa wajib pajak akan patuh jika mereka tidak memiliki kemauan dan kesadaran dalam membayar pajak.

c. Variabel Tax Amnesty berpengaruh signifikan terhadap tingkat kepatuhan wajib pajak orang pribadi dengan $\mathrm{t}$ hitung $=2,409$ dan sig $0,018(0,018<0,05)$. Hal ini menunjukkan bahwa dengan dilaksanakanya Tax Amnesty membuat wajib pajak patuh untuk melakukan pelaporan dan pembayaran pajak yang terutang.

d. Variabel kualitas pelayanan fiskus berpengaruh signifikan terhadap tingkat kepatuhan wajib pajak orang pribadi dengan $\mathrm{t}$ hitung $=2,008$ dan sig 0,048 $(0,048<0,05)$. Hal ini menunjukkan bahwa semakin baiknya pelayanan yang diberikan fiskus mampu memberikan pengaruh terhadap kepatuhan wajib pajak.

e. Variabel kesadaran wajib pajak berpengaruh signifikan terhadap tingkat kepatuhan wajib pajak orang pribadi dengan $\mathrm{t}$ hitung $=2,075$ dan sig 0,041 $(0,041<0,05)$. Hal ini menunjukkan bahwa semakin tinggi tingkat kesadaran wajib pajak, maka semakin tinggi pula tingkat kepatuhan wajib pajak.

f. Variabel penerapan E-SPT tidak berpengaruh signifikan terhadap tingkat kepatuhan wajib pajak orang pribadi dengan t hitung $=0,108$ dan sig $=0,149$ $(0,882>0,05)$. Hal ini menunjukkan dengan adanya Penerapan E-SPT yang tidak diimbangi dengan sosialisasi yang meluas maka tidak akan berpengaruh terhadap kepatuhan wajib pajak. 
g. Nilai koefisien determinasi (R2) yaitu 0,219 atau 21,9\%. Hal ini menunjukan bahwa besar pengaruh variabel independen ketegasan sanksi pajak, pengetahuan pajak,, Tax Amnesty, kualitas pelayanan fiskus, kesadaran wajib pajak, dan penerapan E-SPT terhadap variabel dependen tingkat kepatuhan wajib pajak orang pribadi (WPOP) yang dapat diterangkan oleh model dengan persamaan sebesar $21,9 \%$ dan sisanya $78,1 \%$ dipengaruhi oleh faktor-faktor lain diluar penelitian.

\section{Implikasi}

a. Hasil penelitian ini diharapkan mampu menambah dan memperkaya wawasan dalam bidang perpajakan terutama dalam hal tingkat kepatuhan wajib pajak, dimana hasil penelitian ini berkontribusi dalam menambah bukti empiris mengenai pengaruh ketegasan sanksi pajak, pengetahuan pajak, tax amnesty, kualitas pelayanan fiskus, kesadaran wajib pajak, dan penerapan e-spt terhadap kepatuhan wajib pajak. Penelitian ini juga diharapkan dapat melengkapi penelitian sebelumnya dan dapat pula dijadikan referensi pada penelitian selanjutnya.

b. Diharapkan pihak instansi terkait dalam hal ini Kantor Pelayanan Pajak (KPP) Pratama Batang untuk lebih memberikan informasi kepada seluruh masyarakat perihal perpajakan. Masih kurang tingginya sanksi pajak yang diberikan kepada wajib pajak mengakibatkan kurangnya tanggung jawab masyarakat terhadap pajak. Tax amnesty terbukti berpengaruh terhadap kepatuhan pajak. Apabila sanksi pajak dapat ditingkatkan lagi maka akan membuat wajib pajak merasa terancam apabila tidak memenuhi kewajiban perpajakkannya maka kurangnya penerimaan pajak di Kantor Pelayanan Pajak (KPP) Pratama Kabupaten Batang dapat diminimalisir dan tingkat kepatuhan pajak juga akan semakin tinggi.

\section{DAFTAR PUSTAKA}

Arabella Oentari Fuadi dan Yenni Mangoting. 2012. "Pengaruh Kualitas Pelayanan Petugas Pajak, Sanksi Perpajakan dan Biaya Kepatuhan Pajak Terhadap Kepatuhan Wajib Pajak UMKM”. Program Akuntansi Pajak Program Studi Akuntansi Universitas Kristen Petra.

Bayu Caroko, Heru Susilo dan Zahroh Z.A. 2015. "Pengaruh Pengetahuan Perpajakan, Kualitas Pelayanan Pajak, Sanksi Pajak Terhadap Motivasi Wajib Pajak Orang Pribadi Dalam Membayar Pajak”. Jurnal Perpajakan (JEJAK) Vol.1 No.1 Januari 2015. Universitas Brawijaya.

Dwiatmono, Saktiawan. 2018. "Pengaruh Tax Amnesty, Sanksi Pajak, dan Kualitas Pelayanan Fiskus Terhadap Kepatuhan Wajib Pajak Orang Pribadi Studi Empiris pada Wilayah Kantor Pelayanan Pajak Pratama Sleman”. Skripsi. Universitas Islam Yogyakarta.

Firdaus Aprian Zuhdi, Topowijono, dan Devi Farah Azizah. 2015. "Pengaruh Penerapan E-SPT dan Pengetahuan Perpajakan Terhadap Kepatuhan Wajib Pajak Studi Pada Pengusaha Kena Pajak Yang Terdaftar di KPP Pratama Singosari”. Jurnal Perpajakan (JEJAK) Vol.7 No.1 2015. Universitas Brawijaya.

Gusrefika, Resi. 2018. "Pengaruh Kesadaran Wajib Pajak, Sanksi Pajak, Motivasi Membayar Pajak dan Tingkat Pendidikan Terhadap Kepatuhan Wajib Pajak 
Studi Kasus Pada Wajib Pajak Orang Pribadi di UMKM di KPP Peratama Tampan Pekanbaru". Fakultas Ekonomi dan Bisnis Universitas Riau. Pekanbaru.

http://batangkab.bps.go.id Diakses pada 1 Oktober 2019

https://jateng.tribunnews.com diakses pada 10 September 2019

https://www.cnbcindonesia.com/news/20190726094730-4-87743/miris-ternyata-taxratio-indonesia-terendah-di-asia-pasifik diakses pada 10 September 2019

https://www.cnbcindonesia.com/news/20190726094730-4-87743/miris-ternyata-taxratio-indonesia-terendah-di-asia-pasifik diakses pada 10 September 2019

https://www.pajak.go.id/id/artikel/sudah-cukupkah-kepatuhan-pajak-kita_diakses pada 10 September 2019

I Gusti Ngurah Putra Mahardika.2016. "Pengaruh Kualitas Pelayanan dan Sikap Wajib Pajak Terhadap Kepatuhan Pelaporan Wajib Pajak Orang Pribadi di KPP Pratama Singaraja”.Universitas Pendidikan Ekonomi, FEB Universitas Pendidikan Ganesha. Singaraja.

Jeremiah Reinhart Assa, Lintje Kalangi, dan Winston Pontoh. 2018. "Pengaruh Pemeriksaan Pajak Dan Sanksi Perpajakan Terhadap Kepatuhan Wajib Pajak Pada Kantor Pelayanan Pajak Pratama Manado”. Jurnal Riset Akuntansi Going Concern 13(4), 2018, 516-522. Universitas Sam Ratulangi.

Jotopurnomo, Cindy dan Yenni Mangoting. 2013. "Pengaruh Kesadaran Wajib Pajak, Kualitas Pelayanan Fiskus, Sanksi Perpajakan, Lingkungan Wajib Pajak Berada Terhadap Kepatuhan Wajib Pajak Orang Pribadi di Surabaya”. Universitas Kristen Petra. Tax \& Accounting Review Vol.1, No.1.

Kartini, Ulfah. 2018. "Pengaruh Tax Amnesty dan Sanksi Perpajakan Terhadap Kepatuhan Wajib Pajak Orang Pribadi di KPP Pratama Kabupaten Purworejo”. Universitas Negeri Yogyakarta. Yogyakarta.

Ketut Evi Susilawati dan Ketut Budiartha. 2013. "Pengaruh Kesadaran Wajib Pajak, Pengetahuan Pajak, Sanksi Perpajakan Dan Akuntabilitas Pelayanan Publik Pada Kepatuhan Wajib Pajak Kendaraan Bermotor”. E-Jurnal Akuntansi Universitas Udayana ISSN 2302-8556.

Kirana Cipta Komala, Suhadak, dan Maria Goretti Wi Endang NP.2017. d "Pengaruh Pelayanan Perpajakan Terhadap Kepatuhan Wajib Pajak Badan Studi Kasus Pada KPP Madya Malang”. Universitas Brawijaya.

Lingga, Ita Salsalina. 2012. "Pengaruh Penerapan e-SPT Terhadap Efisien Pemrosesan Data Perpajakan Survey Terhadap Pengusaha Kena Pajak Pada KPP Pratama “X” Bandung”. Jurnal Akuntansi Vol.4 No.2 November 2012 : 101-114. Dosen Fakultas Ekonomi Jurusan Akuntansi Universitas Kristen Maranatha. 
Lingga, Ita Salsalina. 2012. "Pengaruh Penerapan e-SPT Terhadap Kepatuhan Pajak Studi Empiris Terhadap Pengusaha Kena Pajak di Wilayah KPP Pratama " $X$ " Jawa Barat I". Jurnal Akuntansi Vol.5 No.1, hal 50-60, ISSN 2085-8698. Dosen Fakultas Ekonomi Jurusan Akuntansi Universitas Kristen Maranatha.

Mahdi dan Windi Ardianti. 2017. "Pengaruh Kesadaran Wajib Pajak Dan Sanksi Pajak Terhadap Kepatuhan Wajib Pajak Orang Pribadi Pada Kantor Pelayanan Pajak Pratama Banda Aceh”. Jurnal Ekonomi Manajemen dan Akuntansi Vol.3 No.1 e-ISSN 2579-5635 p-ISSN 2460-5891.

Matia, Delli. 2013. "Pengaruh Modernisasi Sistem administrasi Perpajakan Terhadap Tingkat Kepatuhan Pengusaha Kena Pajak di Kantor Pelayanan Pajak Pratama Bandar Lampung”. Jurnal Bisnis Darmajaya Vol.01 no.01, Maret 2013. Jurusan Akuntansi Fakultas Ekonomi Informatics \& Bussiness Institute Darmajaya.

Ni Kadek Intania Kesumsari dan Ketut Alit Suardana. 2018. "Pengaruh Pengetahuan Perpajakan, Kesadaran dan Pengetahuan Tax Amnesty Pada Kepatuhan WPOP di KPP Pratama Gianyar”. E-Jurnal Akuntansi ISSN :2302-8556. Universitas Udayana.

Ni Putu Milan Novita Handayani dan Naniek Noviari. 2016. "Pengaruh Persepsi Manajemen Atas Keunggulan Penerapan E-Billing dan E-SPT Pajak Pertambahan Nilai Pada Kepatuhan Perpajakan”. E-Jurnal Akuntansi Universitas Udayana Vol.15.2 Mei (2016): 1001-1028, ISSN 2302-8556. Universitas Udayana. Bali.

Prasasti S.E.J, Ria. 2017. "Pengaruh Pengetahuan Tentang Pajak, Sanksi Pajak, Dan Pemeriksaan Pajak Terhadap Kepatuhan Wajib Pajak di Kantor Wilayah Direktorat Jenderal Pajak Daerah Istimewa Yogyakarta Tahun 2016”. Skripsi. Universitas Negeri Yogyakarta.

Priambodo, Putut. 2017. "Pengaruh Pemahaman Peraturan Pajak, Sanksi Perpajakan, Kesadaran Wajib Pajak, Terhadap Kepatuhan Wajib Pajak Orang Pribadi di Kantor Pelayanan Pajak Pratama Kabupaten Purworejo Pada Tahun 2017”. Skripsi. Fakultas Ekonomi Universitas Negeri Yogyakarta.

Purwanti, Meilani dan Surini. 2016. "Pengaruh E-Registration, E-SPT, dan E-Filling Terhadap Kepatuhan Wajib Pajak".Bandung Business School. ISSN 16934482. www.stiestembi.ac.id/?\&c=jurnal-star.

Rahayu, Nurulita. 2017. "Pengaruh Pengetahuan Perpajakan, Ketegasan Sanksi Pajak, dan Tax Amnesty Terhadap Kepatuhan Wajib Pajak”. Jurnal Akuntansi Dewantara Vol.1 No.1 April 2017 p-ISSN 2550-0376, e-ISSN 2549-9637. Universitas Sarjanawiyata Tamansiswa Yogyakarta.

Rahayu, Sri dan Ita Salsalina Lingga. 2009. "Pengaruh Modernisasi Sistem Administrasi Perpajakan Terhadap Kepatuhan Wajib Pajak Survei atas Wajib 
Pajak Badan pada KPP Pratama Bandung X’. Jurnal Akuntansi Vol.1 No.2 November 2009:119-138. Universitas Kristen Maranatha.

Riadita, Farah Alifa dan Saryadi. 2017. " Pengaruh Kualitas Pelayanan, Kesadaran Wajib Pajak, dan Pengetahuan Pajak Terhadap Kepatuhan Wajib Pajak Studi Pada UMKM Yang Terdaftar di KPP Pratama Semarang Selatan”. Semarang.

Sixvana Silalahi, Mochammad Al Musadieq, dan Gunawan Eko Nurtjahjono. 2015. "Pengaruh Kualitas Pelayanan Perpajakan Terhadap Kepuasan Wajib Pajak, Kepatuhan Wajib Pajak Dan Penerimaan Pajak Studi Pada Kantor Pelayanan Pajak Madya Malang”. Jurnal Perpajakan (JEJAK) Vol.1 No.1 Januari 2015. Universitas Brawijaya.

Tryana A.M. Tiraada. 2013. "Kesadaran Perpajakan, Sanksi Pajak, Sikap Fiskus Terhadap Kepatuhan WPOP di Kabupaten Minahasa Selatan”. Universitas Sam Ratulangi Manado. ISSN 2303-1174.

Umatun Markhumah, Triyono, dan Noer Sasongko. 2019. "Pengaruh Ketegasan Sanksi Pajak, Pengetahuan Pajak, TAX AMNESTY, Pelayanan Fiskus, Reformasi Perpajakan Terhadap Kepatuhan Wajib Pajak Studi Empiris Pada Wajib Pajak Badan di KPP Pratama Surakarta”. Universitas Muhammadiyah Surakarta.

Viega Ayu Permata Sari dan Fidiana .2017. "Pengaruh Tax Amnesty, Pengetahuan Perpajakan, dan Pelayanan Fiskus Terhadap Kepatuhan Wajib Pajak”. Jurnal Ilmu dan Riset Akuntansi. Sekolah Tinggi Ilmu Ekonomi Indonesia . Surabaya.

Winerungan, Oktaviane Lidya. 2013. "Sosialisasi Perpajakan, Pelayanan Fiskus dan Sanksi Perpajakan Terhadap Kepatuhan WPOP di KPP Manado dan KPP Bitung". Jurnal EMBA Vol.1 No.3 September 2013, Hal 960-970 ISSN 23031174. Fakultas Ekonomi dan Bisnis Jurusan Akuntansi, Universitas Sam Ratulangi Manado.

www.online-pajak.com diakses pada 10 September 2019

www.ortax.org diakses pada 10 September 2019

www.pajak.go.id diakses pada September 2019

Yuli Anita Siregar, Drs. Saryadi, dan Sari Listyorini. "Pengaruh Pelayanan Fiskus Dan Pengetahuan Perpajakan Terhadap Kepatuhan Wajib Pajak Studi Empiris Terhadap Wajib Pajak di Semarang Tengah”. Universitas Diponegoro. Semarang. 